ORIGINAL ARTICLES, MEDICINE

\title{
Progressive Scoliosis and Syringomyelia - Questions of Surgical Approach
}

\author{
Mikhail Mikhaylovskiy, Vyacheslav Stupak, Vadim Belozerov, Nikolay Fomichev, Anatoliy \\ Lutsik, Leonid Afanasyev, Anatoliy Bondarenko, Alexandr Krutko, Dmitriy Dolzhenko, Alla \\ Zaidman, Valeriy Larkin, Andrey Narodov, Alexander Novokshonov, Samuil Rabinovich, Vic- \\ tor Rerikh, Valeriy Prokhorenko, Olga Falameeva, Vladimir Shevtsov, Mikhail Sadovoy \\ Novosibirsk Research Institute of Traumatology and Orthopaedics n.a. Ya.L. Tsivyan, Novosibirsk, Russia
}

Correspondence: Mikhail Mikhaylovskiy, Department of Scoliosis, Research Institute of Traumatology and Orthopedics n.a. Ya.L. Tsivyan, 17 Frunze Str., 630091 Novosibirsk, Russia

E-mail: Mikhail.v.Mikhaylovskiy@ gmail.com

Tel: +79130079321

Received: 06 Dec 2016

Accepted: 27 Sept 2017

Published Online: 20 Nov 2017

Published: 30 June 2018

Key words: syringomyelia, idiopathic scoliosis, correction of spinal deformity

Citation: Mikhaylovskiy M, Stupak V, Belozerov V, Fomichev $\mathrm{N}$, Lutsik A, Afanasyev L, Bondarenko A, Krutko A, Dolzhenko D, Zaidman A, Larkin V, Narodov A, Novokshonov A, Rabinovich S, Rerikh V, Prokhorenko V, Falameeva O, Shevtsov V, Sadovoy M. Progressive scoliosis and syringomyelia - questions of surgical approach. Folia Med (Plovdiv) 2018;60(2):261-9.

doi: 10.1515/folmed-2017-0099
Background: The rate of scoliosis in syringomyelia patients ranges from 25 to $74.4 \%$. In turn, syringomyelia occurs in $1.2 \%$ to $9.7 \%$ of scoliosis patients.

Aim: To evaluate outcomes of surgical correction of the scoliotic deformity in syringomyelia patients.

Materials and methods: Between 1996 and 2015, 3120 patients with scoliosis of various etiologies were treated at the Clinic for Child and Adolescent Vertebrology of the Novosibirsk Research Institute of Traumatology and Orthopedics. We conducted a retrospective analysis of syringomyelia-associated scoliosis cases that required surgical correction.

Results: Syringomyelia was found in 33 patients (1.05\%) out of 3120 patients with spinal deformities of various etiologies; in 21 patients $(0.9 \%)$ with idiopathic scoliosis of 2334 patients. In identifying the neurological deficit, the recommended first step is to perform neurosurgery. Nineteen patients were operated using the CDI, 4 patients underwent correction VEPTR, in 1 case instrumentation could not be established, 9 patients are undergoing treatment in the department of neurosurgery at the moment. Worsening of neurological deficits was not observed in any patient.

Conclusion: A comparison of the results of syringomyelia-associated scoliosis correction with the data of other authors was done. The choice of surgery tactics is strictly individual and depends on the size of the cavity. The result of surgical intervention is generally positive and the loss of correction by the end of follow-up is negligible.

\section{BACKGROUND}

The rate of scoliosis in syringomyelia patients ranges from 25 to $74.4 \% .^{1,2}$ Syringomyelia occurs in $1.2 \%$ to $9.7 \%$ of scoliosis patients. ${ }^{1,3-9}$ It should also be noted that syringomyelia is associated with Arnold-Chiari malformation in $30 \%$ to $86 \%$ of cases. ${ }^{7,10-12}$ This combination makes it necessary to extend the amount of both preoperative examination and neurosurgery.
The use of modern technologies enables detection of most comorbidities, in particular at the preoperative preparation stage, which helps to choose an appropriate treatment option as well as predict and significantly reduce the risk of intra- and postoperative complications. Despite this, the problem of choosing a treatment option for combination of scoliosis and syringomyelia is still topical. In the literature, there are many reports on outcomes of 
surgical treatment in these patients and diagnostic issues, but there is no common strategy or algorithm of actions. A variety of techniques and procedures have been developed for treatment of syringomyelia, but none of them, except surgery, provides the results that would enable early correction of a scoliotic deformity with a minimum risk of neurological complications. Despite the fact that many authors have described cases of spontaneous cyst collapse, long-term ineffective conservative treatment may lead to a severe progression of scoliosis. A neurosurgical intervention, in turn, also does not provide a perfect result; often, re-operation is required, or the surgery outcome actually is such that scoliosis correction cannot be performed with the minimum risk. Therefore, the patient with syringomyelia and scoliosis is always a particular case in terms of choosing a treatment option. The main questions that surgeons face are as follows: How safe is the correction of a spinal deformity associated with syringomyelia? What cases require neurosurgery to be performed before correction? What is surgery tactics in the absence of indications for neurosurgery? Is the use of intraoperative traction reasonable?

Researchers' opinions on the issues are very controversial. Therefore, the purpose of our study was to evaluate the outcome of surgical correction of the scoliotic deformity in syringomyelia patients.

\section{MATERIALS AND METHODS}

\section{Patients}

Three thousand one hundred and twenty patients with scoliosis of various etiologies were treated at the Clinic for Child and Adolescent Vertebrology of the Novosibirsk Research Institute of Traumatology and Orthopedics between 1996 and 2015. We conducted a retrospective analysis of 33 syringomyelia-associated scoliosis cases that required surgical correction. Syringomyelia was diagnosed in 33 patients $(1.05 \%)$. Syringomyelia associated with idiopathic scoliosis was diagnosed in $21(0.9 \%)$ out of 2334 patients; syringomyelia associated with scoliosis of other etiologies (congenital and paralytic) was detected in $12(1.52 \%)$ out of 786 patients.

\section{DiAgNOSTIC METHODS}

At admission to the clinic, all patients underwent a standard preoperative examination that necessarily involved MRI of the thoracic spine, MRI of a segment comprising the curve apex, and examination by a neurologist. In the case of gross deformities (more than $80^{\circ}$ ), patients detected with spinal cord cysts additionally underwent a traction test with patient's total body weight as well as electroneuromyography and evoked potential tests. If cysts were identified in the thoracic or upper thoracic spinal cord, MRI of the cervical spine and craniovertebral junction was performed.

\section{SURGICAL METHODS}

Additional neurosurgery stage was performed in 20 patients. In 17 cases, syringomyelia was diagnosed incidentally at the stage of preoperative MRI. Three patients were diagnosed with syringomyelia before admission to the clinic. The following interventions were performed: formation of the cisterna magna, drainage and emptying of cysts, and resection of the filum terminale. Syringomyelia associated with a Chiari malformation was present in 14 (42.4\%) patients. Cord-traction syndrome was present in 2 patients, which was the reason for resection of the filum terminale.

\section{Statistical analysis}

The data were analyzed with STATISTICA 7.0 software (StatSoft, Tulsa, OK, USA). Independent samples (different patients groups) were tested for statistical significance using non-parametric MannWhitney and Kruskal-Wallis tests. Dependent samples (before and after surgery) were tested for statistical significance using the Wilcoxon test. The data are presented as the median and interquartile range.

\section{DISCUSSION}

We conducted a retrospective analysis of 33 syringomyelia-associated scoliosis cases that required surgical correction. In orthopedic correction, the CDI instrumentation was used in 19 patients, the VERT instrumentation was used in 4 patients, and neurosurgery alone was performed in 9 patients. Detailed characteristics of patients are given in Table 1. Based on the baseline characteristics and risk factors, the basic principles for treatment of these patients were defined.

\section{NeURosurgical InTERVENTIONS}

Nineteen patients underwent the following neurosurgical interventions: 1) cisterna magna formation and cyst evacuation (9 patients); 2) isolated evacuation of a cyst (7 patients); 3) cisterna magna formation without cyst evacuation (3 patients). Repeated surgery was required in three cases; it included re-evacuation of cysts and reconstruction with dura mater fragments.

A neurological deficit of varying severity, which 


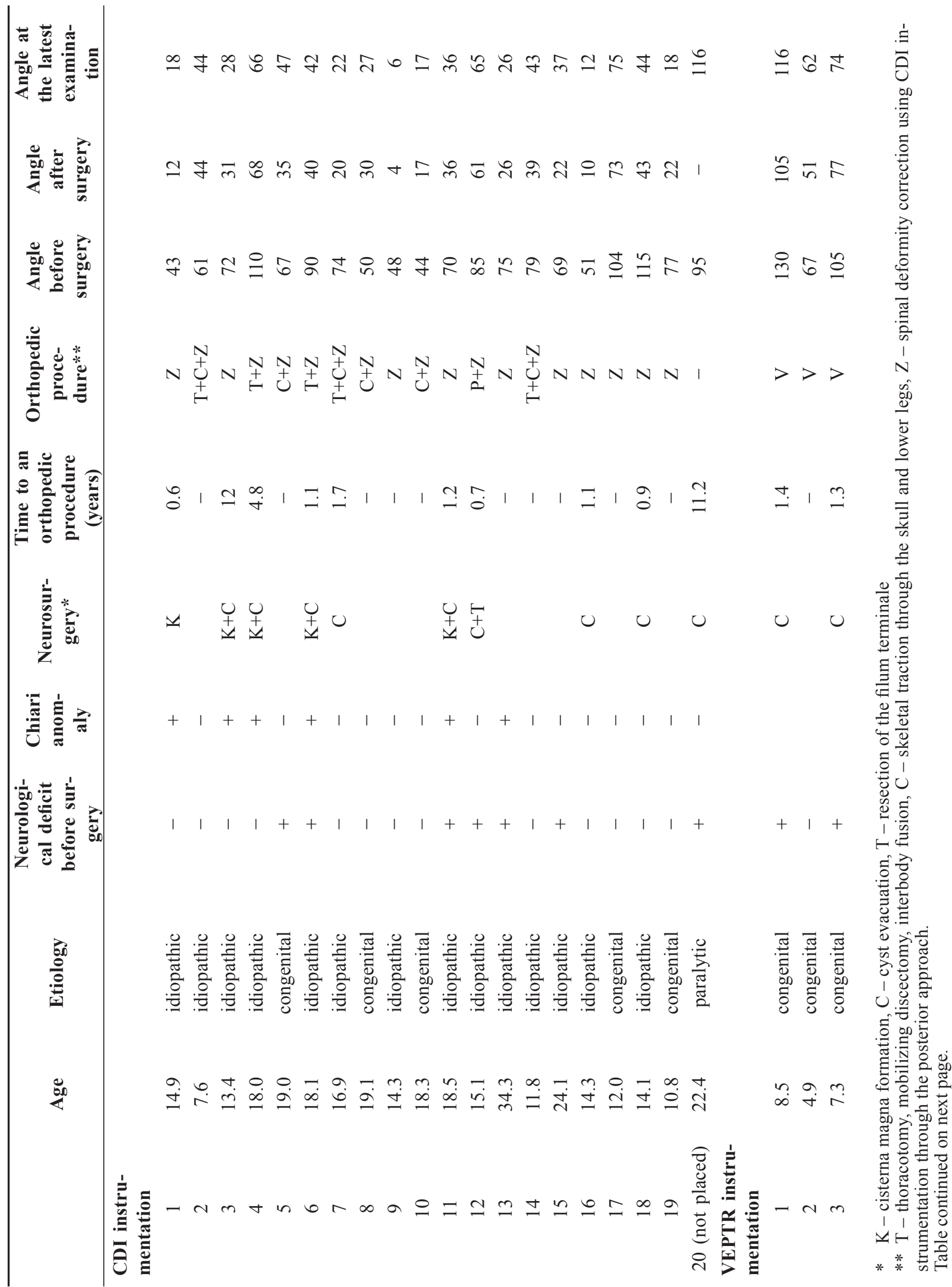


M. Mikhaylovskiy et al

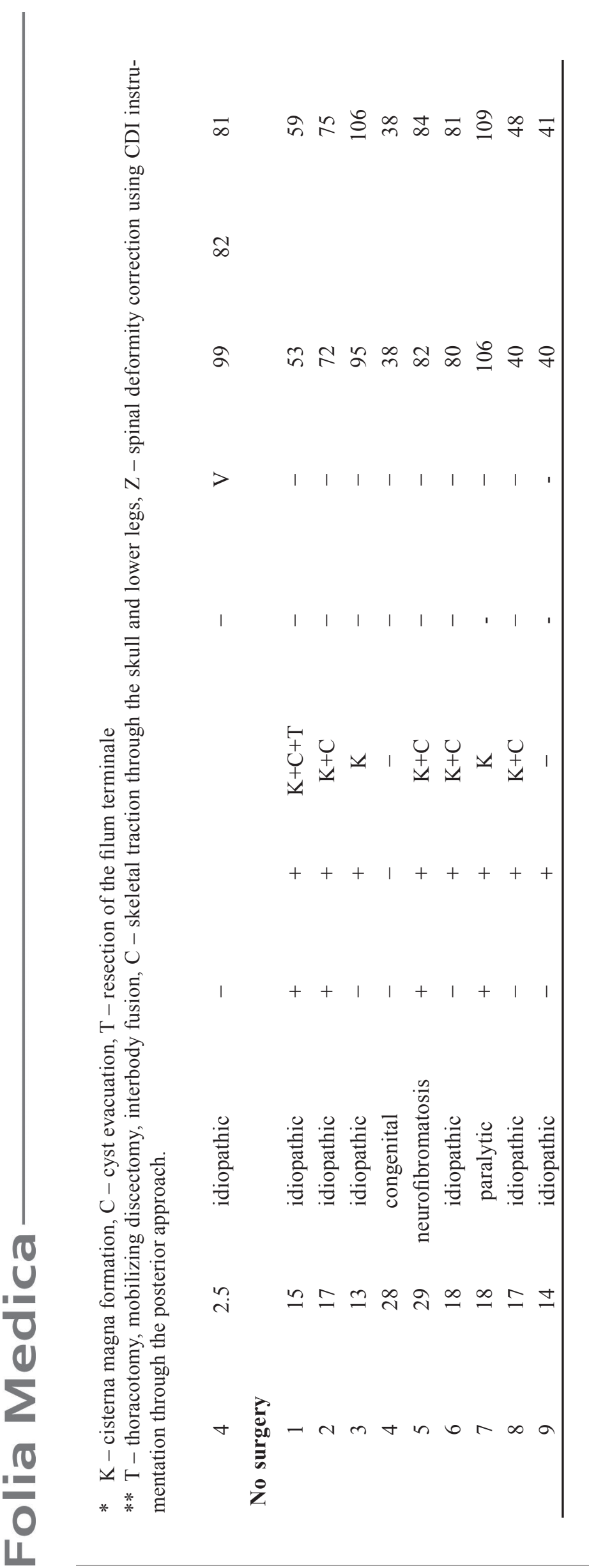


was the reason we suspected spinal cord malformations, was observed in 13 patients; in one patient, neurological deficit was detected only during registration of evoked potentials (there were no clinical manifestations).

Two patients underwent neurosurgery aged less than 10 years. After neurosurgery, the scoliotic deformity continued to progress in both cases: from $81^{\circ}$ to $105^{\circ}$ and from $119^{\circ}$ to $130^{\circ}$, respectively, for one year. In a group of patients who underwent neurosurgery at the age of 10 to 17 years (11 patients), scoliosis also continued to progress. The remaining 7 patients underwent neurosurgery after the end of active bone growth at the age of 17 years or more; after neurosurgical treatment, the scoliotic deformity in these patients was in a stable condition, without clinically significant progression (Table 1).

At the time of paper preparation, nine patients continued treatment and were followed up by neurosurgeons. Two of these patients had no neurosurgery due to the absence of neurological symptoms, small cavity size, absence of the indications for immediate scoliosis surgery because of minor severity of the scoliotic curve $\left(38^{\circ}\right.$ and $40^{\circ}$, respectively) and a lack of deformity progression. The patients were followed up. In eight patients in this group who had no scoliosis correction, syringomyelia was associated with an Arnold-Chiari malformation.

\section{ORTHOPEDIC SURGERY}

The median age of 23 patients who underwent spinal deformity correction using various instrumentation was 14.6 (IQR 12.3-18.4) years at the time of surgery ( 2.5 to 34.3 years). There was no statistically significant relationship between the gender, age, curve apex, scoliotic curve direction, rate of progression, neurological symptoms, and presence of syringomyelia. Neurological deficit was noted to start developing when the cyst extended more than 4 $\mathrm{mm}$. In this case, the length and location of the cyst did not play a significant role. Interestingly, in the case of cysts of up to $9 \mathrm{~mm}$ in width, the clinical signs and neurological symptoms could be absent. The cyst localization was as follows: 8 cysts in the cervical spine; 15 cysts in the cervicothoracic spine; 8 cysts in the thoracic spine; 1 cyst in the lumbar spine; 1 cyst in the filum terminale.

In cases of no neurological deficit and the syrinx width of less than $4 \mathrm{~mm}$, the deformity was corrected through the posterior approach under skeletal traction (Fig. 1). Dorsal correction alone was carried out in 10 cases. In three cases, the step of placing CDI instrumentation was complemented with mobilizing discectomy. Also, three-stage surgery (mobilizing discectomy, skeletal traction, deformity correction with dorsal instrumentation) was performed in 3 cases. If after neurosurgery, neurological symptoms did not regress completely, or syrinxes were larger than $4 \mathrm{~mm}$, surgical correction of the spinal deformity was performed without skeletal traction (Fig. 2).

\section{SURGERY}

CDI instrumentation was planned to be used for surgery of 20 patients with mean age of 16.0 (IQR 13.8-18.8) years. The mean follow-up period was 4 years (IQR 2-5.6) (1.6 to 11.9 years). Preoperatively, all patients underwent a traction test under patient's total body weight, which showed no worsening of neurological symptoms. The patients were consulted by neurosurgeons who jointly decided on the tactics and amount of surgery. The primary scoliotic curve was located in the thoracic spine in 28 cases and in the lumbar spine in 5 cases. The median magnitude of the primary scoliotic curve before surgery was $69.5^{\circ}$ (IQR $54.5^{\circ}-87.5^{\circ}$ ), and the mean compensatory curve was $31^{\circ}$ (IQR $0^{\circ}-54^{\circ}$ ). The thoracic kyphosis before surgery was $35.5^{\circ}$ (IQR $26.5^{\circ}-56.5^{\circ}$ ). The lumbar lordosis was $69.5^{\circ}$ (IQR $57.5^{\circ}-77^{\circ}$ ). Implantation of an endocorrector failed in one patient $(5.3 \%)$. The dural ectasia signs were detected during preoperative examination. Intraoperatively, excessive liquorrhea developed during an attempt to place laminar hooks, which caused the decision to refuse scoliosis correction.

After surgery, the mean magnitude of the primary curve was $33^{\circ}$ (IQR $20^{\circ}-43^{\circ}$ ); the mean compensatory curve was $4^{\circ}\left(\operatorname{IQR} 0^{\circ}-25^{\circ}\right)$; thoracic kyphosis amounted to $23^{\circ}$ (IQR $15^{\circ}-32^{\circ}$ ); lumbar lordosis was $50^{\circ}\left(\mathrm{IQR} 48^{\circ}-61^{\circ}\right)$. Thus, the primary curve correction was $35^{\circ}$ (IQR $\left.31^{\circ}-47^{\circ}\right)(55.6 \%$, IQR $40 \%-71.4 \%)$; the secondary curve correction (among patients with non-zero lumbar compensatory curve) was 34 (IQR $\left.26^{\circ}-41^{\circ}\right)(65.3 \%$, IQR $55.8 \%-78.8 \%)$, that states significant improvement $(p<0.001)$. At the end of the follow-up period, postoperative progression was $0^{\circ}\left(\operatorname{IQR} 0^{\circ}-4^{\circ}\right)$ for the primary curve and $2^{\circ}$ (IQR $0^{\circ}-4^{\circ}$ ) for the secondary curve and failed to reach statistical significance $(\mathrm{p}=0.118)$. Surgical correction of the spinal deformity did not lead to worsening of neurological symptoms in any of the cases.

\section{SURGERY WITH VEPTR DEVICE}

At the time of paper preparation, four patients were at different stages of treatment with a VEPTR device; all of them had congenital spinal deformities; the 


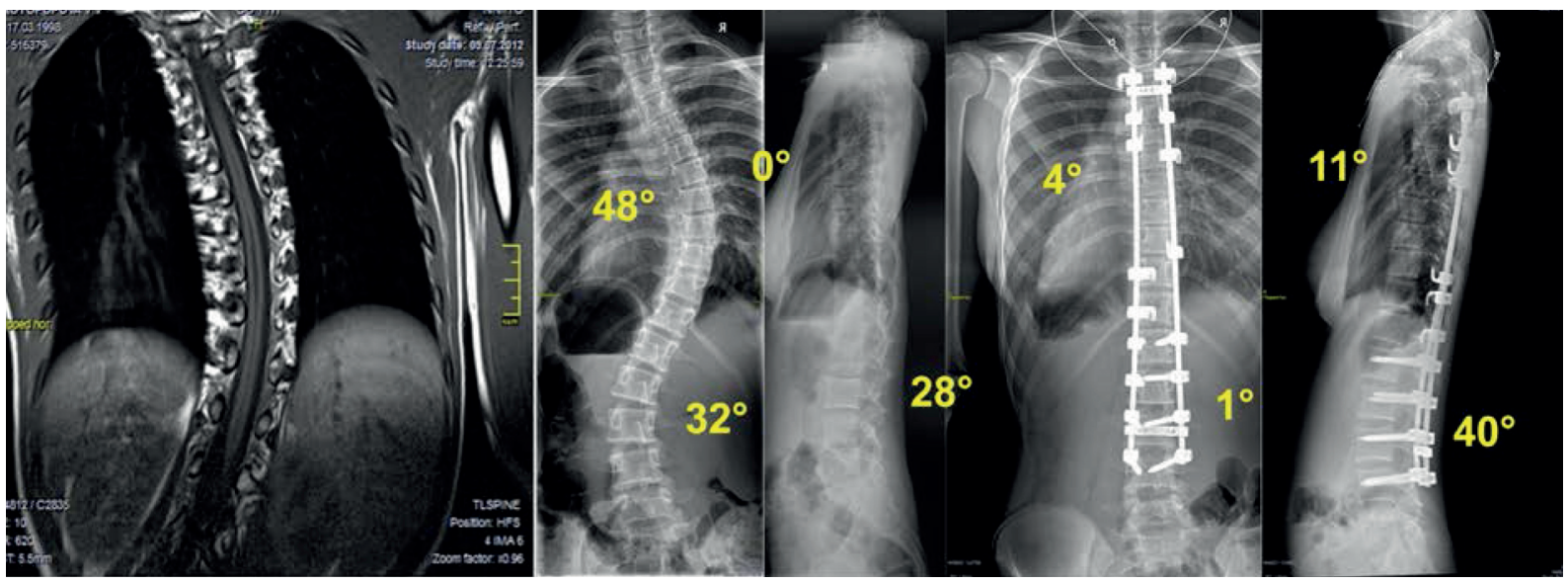

Figure 1. Clinical case 2. A 14-year-old female patient P. Correction of scoliosis under skeletal traction, without prior neurosurgery.
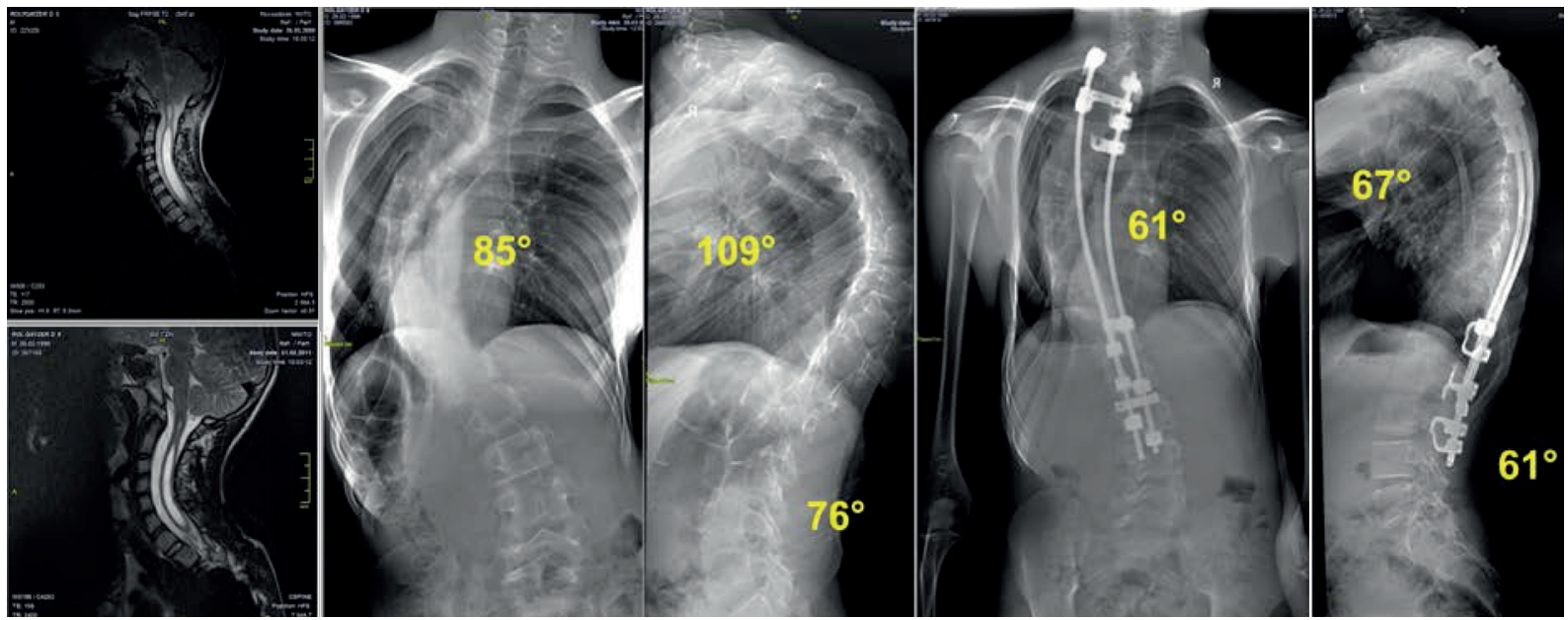

Figure 2. Clinical case 3. A 15-year-old male patient R. Cisterna magna formation, syrinx drainage, partial regression of neurological symptoms, and correction of the spinal deformity without intraoperative traction.
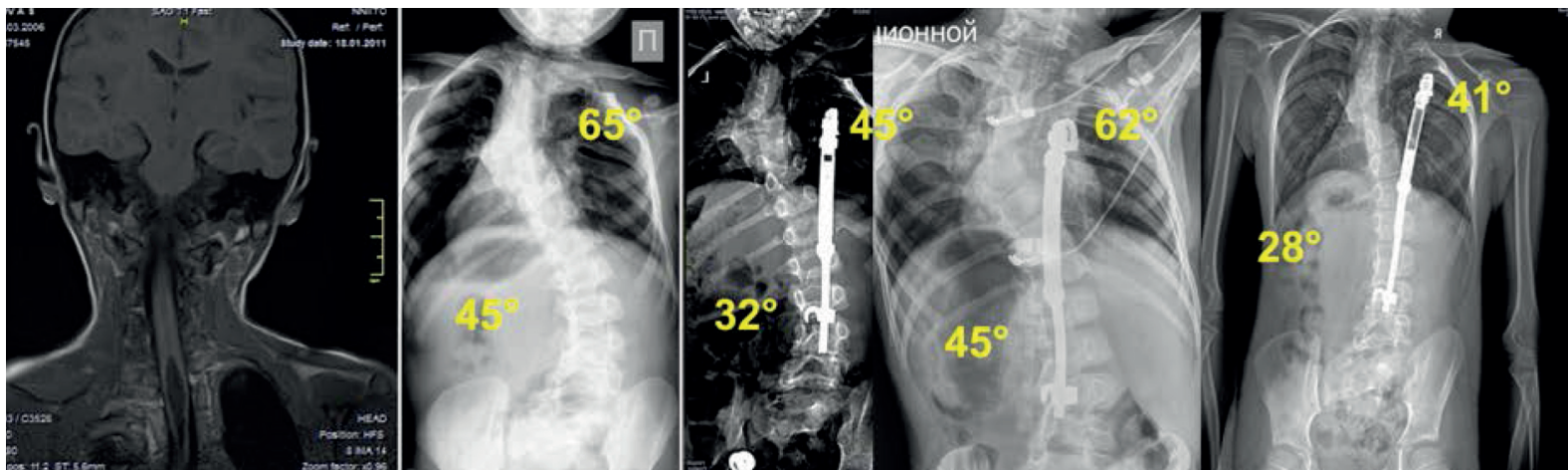

Figure 3. Clinical case 1. A 5-year-old male patient G. Stages of surgical correction using a VEPTR device. 
mean age of surgery was 5.8 years (range, 2.5 to 8.5 years). An initial mean deformity of $100.3^{\circ}$ (67 $7^{\circ}$ to $130^{\circ}$ ) was reduced to $78.8^{\circ}\left(51^{\circ}\right.$ to $\left.105^{\circ}\right)$, on average, after primary correction. Subsequent treatment stages involved $1.5-2 \mathrm{~cm}$ distraction (Fig. 3). There was no neurological deficit worsening associated with primary correction and stepwise distraction. In this group, 2 patients required neurosurgical treatment. According to the MSCT data, both patients were diagnosed with diastematomyelia: at the L2-3 level in the first case and at the T11-12 level in the second case. Initially, both children were diagnosed with lower flaccid paraparesis, which was associated with pelvic organ dysfunction in one case. The patients underwent evacuation of the syrinx without resection of bony septa. The intersurgical interval was 6 months. In both cases, the spinal deformity continued to progress after neurosurgical treatment.

\section{DISCUSSION}

Analysis of the literature shows that some authors prefer to perform first a neurosurgical treatment, arguing that a neurosurgical intervention conducted at the age less than 10 years can completely eliminate the need for scoliosis correction. ${ }^{14-16}$ Other authors tend to believe that preceding neurosurgery can significantly reduce the risk of potential neurosurgical complications during scoliosis correction, but does not stop progression of the deformity. ${ }^{16-18}$ The number of reports on scoliosis correction without any neurosurgical treatment is much more limited, but this surgery is performed under intraoperative neuromonitoring. ${ }^{19-22}$ Despite the difference in approaches, almost all authors agree that the risk of complications associated with scoliotic deformity correction is very significant. At the same time, there is only one report of postoperative complications. Ozerdemoglu et al. reported that 3 of $38(8 \%)$ patients developed neurological complications after scoliotic deformity correction. ${ }^{18}$

A comparison of the results of syringomyeliaassociated scoliosis correction with the data of other authors ${ }^{20-22}$, reporting primary curve correction in a range of 63 to $80 \%$ who used shortening vertebrotomy techniques (vertebral column resection - VCR) and pedicle subtraction osteotomy (PSO) demonstrates that the achieved results are satisfactory. In this case, the absence of neurological complications is a major indicator underlying the choice of a treatment option. Perhaps, more aggressive surgical tactics might provide more significant correction of the primary scoliotic curve, but the risk of neurological deficit worsening might also increase. The use of modern intraoperative neuromonitoring that enables real-time tracking of the effect of any corrective procedure may help increase the degree of spinal deformity correction.

Also, no neurological deficit in studies where authors achieved scoliosis correction of up to $80 \%$ of the initial magnitude of the curve without preceding neurosurgery, including application of shortening vertebrotomy techniques, makes this method very attractive.

Another question that arises before the surgeon performing scoliosis correction is the ability to control the spinal cord conditioning the postoperative period. An implanted metal device complicates visualization of the spinal cord during MRI. A MSCT study, even with contrast enhancement, may also lack sufficient data for full assessment of the cyst size. The syrinx size and central canal lumen can vary over time, not exclusively reduce. Upon extension of lesions and compression of the spinal cord structures, when the structures exhaust their compensatory potential, the neurological status can worsen. In this case, it is necessary to remove the corrective device, perform additional examination, and make a decision on the need for neurosurgical care. We did not observe such cases. Removal of instrumentation may be associated with a potential significant loss of correction. In this regard, the quality of dorsal spine fusion is of particular importance. A secure bone block is a prerequisite for preserving the achieved correction.

Despite the fact that neurological deficit can occur during spinal canal dilatation starting with 4-5 $\mathrm{mm}$, it is impossible to predict changes in the neurological status due to scoliosis correction. Probably, even the maximum correction will not lead to neurological deficit worsening. On the other hand, in the case of a syrinx size of 8-9 $\mathrm{mm}$ and the absence of initial neurological symptoms, even the minimum correction associated with a spinal cord dislocation may impair compensation of the spinal cord condition.

In our opinion, the major advantage of this study is the first experience of using a quantitative evaluation of the intracerebral cavity in planning of surgery for the patient with a combination of syringomyelia and progressive scoliosis. In turn, the main drawback is the limited number of cases. Therefore, further research is required to confirm, detail, or disprove the proposed approach. 


\section{CONCLUSIONS}

For an effective collaboration between neurosurgeons and orthopedists in correcting scoliotic deformities in syringomyelia patients, we propose an approach based on a quantitative evaluation of the cavity width. We have demonstrated that a cavity width of $4 \mathrm{~mm}$ is the borderline level for choosing a surgical approach. If the cavity width is less than $4 \mathrm{~mm}$, we recommend performing orthopedic surgery first and neurosurgery at the second stage. If the cavity width exceeds $4 \mathrm{~mm}$, the thickness of deformity walls is reduced compared to the normal values, and the risk of damage to the nerve pathways during orthopedic surgery increases. In this case, we recommend neurosurgery with drainage of the deformity cavity as the first stage.

\section{REFERENCES}

1. Hausmann ON, Böni T, Pfirrmann CW, et al. Preoperative radiological and electrophysiological evaluation in 100 adolescent idiopathic scoliosis patients. Eur Spine J 2003;12(5):501-6.

2. Kołban M, Darczuk J, Chmielnicki M. Diagnosis of syringomyelia and Chiari malformations in patients with scoliosis. Ortop Traumatol Rehabil 2005;7(1):36-41.

3. Mendelevich EG, Davletshina RI, Dunin DN. [Clinical and MRI outcomes of syringomyelia in children.] Nevrologicheskiy vestnik 2011;4:14-9 (Russian).

4. Krupina NE, Patyukov SV. [To the question about the somatosensory system condition in patients with Chiari malformation type I and syringomyelia on the base of the evoked potentials data.] Ural Medical Journal. 2011;2:32-5 (Russian).

5. Umarhodzhaev F, Ganiev A, Salamatov G. Surgical correction of the scoliosis complicated by the myelosyringosis (case from the practice). Medical Health and Science Journal 2011;6(2):108-111.

6. Mikhaylovskiy MM, Fomichev NG. Surgery of spinal deformities. Spine Surgery 2011;1:281-2.

7. Bradley LJ, Ratahi ED, Crawford HA, et al. The outcomes of scoliosis surgery in patients with syringomyelia. Spine 2007;32(21):2327-33.

8. Charry O, Koop S, Winter R, et al. Syringomyelia and scoliosis: a review of twenty-five pediatric patients. J Pediatr Orthop 1994;14(3):309-17.

9. Kontio K, Davidson D, Letts M. Management of scoliosis and syringomyelia in children. J Pediatr
Orthop 2002;22(6):771-9.

10. Dobbs MB, Lenke LG, Szymanski DA, et al. Prevalence of neural axis abnormalities in patients with infantile idiopathic scoliosis. J Bone Joint Surg Am 2002;84-A(12):2230-4.

11. Fujimori T, Iwasaki M, Nagamoto $\mathrm{Y}$, et al. The utility of superficial abdominal reflex in the initial diagnosis of scoliosis: a retrospective review of clinical characteristics of scoliosis with syringomyelia. Scoliosis 2010;5:17.

12. Ozerdemoglu RA, Denis F, Transfeldt EE. Scoliosis associated with syringomyelia: clinical and radiologic correlation. Spine 2003;28(13):1410-7.

13. Sengupta DK, Dorgan J, Findlay GF. Can hindbrain decompression for syringomyelia lead to regression of scoliosis? European Spine Journal 2000;9(3):198-201.

14. Wang Y, Xie J, Zhang Y, et al. One-stage posterior approach and pedicle instrumentation for correction of scoliosis associated with Chiari I malformation in adolescent. Spine 2014;39(4):294-9.

15. Singhal R, Perry DC, Prasad S, et al. The use of routine preoperative magnetic resonance imaging in identifying intraspinal anomalies in patients with idiopathic scoliosis: a 10-year review. Eur Spine J 2013;22(2):355-9.

16. Hanieh A, Sutherland A, Foster B, et al. Syringomyelia in children with primary scoliosis. Child's Nervous System 2000;6(4):200-2.

17. Woods WW, Pimenta AM. Intramedullar lesions of spinal cord: study of sixty eight consecutive cases. Arch Neurol Phychiatry 1944;52:383-99.

18. Yeom JS, Lee CK, Park KW, et al. Scoliosis associated with syringomyelia: analysis of MRI and curve progression. Eur Spine J 2007;16(10):1629-35.

19. Mendelevich EG, Davletshina RI, Valieva LK. [Clinical outcomes of syringomyelia in different age groups.] Nevrologicheskiy vestnik 2012;4:4550 (Russian).

20. Muhonen MG, Menezes AH, Sawin PD, et al. Scoliosis in pediatric Chiari malformations without myelodysplasia. J Neurosurg 1992;77(1):69-77.

21. Yu KY, Shen JX, Qiu GX, et al. Selective thoracic fusion in the scoliosis associated with syringomyelia. Zhonghua WaiKeZaZhi 2011;49(7):627-30

22. Zhang HQ, Deng A, Liu SH, et al. Adult thoracolumbar or lumbar scoliosis with Chiari malformation and syringomyelia: a retrospective study of correction and fusion strategies. Arch Orthop Trauma Surg 2011;131(4):475-80. 


\title{
Прогрессирующий сколиоз и сирингомиелия - особенности хирур- гической тактики
}

\author{
Михаил Михайловский, Вячеслав Ступак, Вадим Белозёров, Николай Фомичев, Анатолий \\ Луцик, Леонид Афанасьев, Анатолий Бондаренко, Александр Крутко, Дмитрий Должен- \\ ко, Алла Заидман, Валерий Ларкин, Андрей Народов, Александр Новокшонов, Самуил \\ Рабинович, Виктор Рёрих, Валерий Прохоренко, Ольга Фламеева, Владимир Шевцов, \\ Михаил Садовой
}

Новосибирский НИИ травматологии и ортопедии им. Я. Л. Цивьяна, Новосибирск, Россия

Адрес для корреспонденции:

Михаил Михайловский, Кафедра сколиоза, Новосибирский НИИ травматологии и ортопедии им. Я.Л.Цивьяна, ул. им. Фрунзе 17, 630091 Новосибирск, Россия E-mail: Mikhail.v.Mikhaylovskiy@ gmail.com

Tel: +79130079321

Дата получения: 06 декабря 2016

Дата приемки: 27 сентября

2017

Дата онлайн публикации: 20 ноября 2017

Дата публикации: 30 июня 2018

Ключевые слова: сирингомиелия, идиопатический сколиоз, коррекция деформации позвоночника

\section{Образец цитирования:} Mikhaylovskiy M, Stupak V, Belozerov $\mathrm{V}$, Fomichev N, Lutsik A, Afanasyev L, Bondarenko A, Krutko A, Dolzhenko D, Zaidman A, Larkin V, Narodov A, Novokshonov A, Rabinovich S, Rerikh V, Prokhorenko V, Falameeva O, Shevtsov V, Sadovoy M. Progressive scoliosis and syringomyelia - questions of surgical approach. Folia Med (Plovdiv) 2018;60(2):261-9. doi: 10.1515/folmed-2017-0099
Введение: У пациентов с сирингомиелией частота сколиоза колеблется в пределах 25,0 - 74,4\%. В свою очередь, сирингомиелия встречается в 1,2\% 9,7\% случаев среди пациентов со сколиозом.

Цель: Анализ результатов хирургической коррекции сколиотической деформации у пациентов с сирингомиелией.

Материалы и методы: В период с 1996 по 2015 год в клинике детской и подростковой вертебрологии Новосибирского научно-исследовательского института травматологии и ортопедии прошли лечение 3120 пациентов со сколиозом различной этиологии. Мы провели ретроспективный анализ случаев сколиоза, связанных с сирингомиелией, которые потребовали хирургической коррекции.

Результаты: Сирингомиелия была выявлена у 33 пациентов $(1,05 \%)$ из числа 3120 пациентов с деформациями позвоночника различной этиологии; у 21 пациента (0,9\%) с идиопатическим сколиозом из числа 2334 пациентов. При выявлении неврологического дефицита рекомендуемым первым шагом является проведение нейрохирургического вмешательства. Девятнадцать пациентов были оперированы с использованием инструментария CD, 4 пациента прошли коррекцию инструментарием VEPTR, в 1 случае не удалось установить инструментарий, 9 пациентов проходят лечение в отделении нейрохирургии на данный момент. Ухудшение неврологического дефицита не наблюдалось ни у одного из пациентов.

Заключение: Проведено сравнение результатов коррекции сколиоза, связанного с сирингомиелией, с данными других авторов. Выбор тактики операции строго индивидуальный и зависит от размера полости. Результат хирургического вмешательства в целом положительный, и потеря коррекции до конца контрольного периода незначительна. 